\title{
An essay in Russian schools: background information and current state
}

\author{
Elena V. Getmanskaya ${ }^{1}$ and Sergey A. Zinin ${ }^{1, *}$ \\ ${ }^{1}$ MSPU, Philology and Foreign Languages Institute, 129226, Moscow, Russia
}

\begin{abstract}
In the article the basic methodological problems associated with the return of the final essay to the Russian school practice have been considered. The synchronic and diachronic analysis provided in the article defines a meta-methodological character of an essay, recreating the criteria of assessment, thematic and genre transformation of an essay as the basic conditions for its success. The article contains different views of scientists on further improvement of this form of final control..
\end{abstract}

One hundred years ago the quality of literary education of a graduate of the Russian grammar school, preparing for entering the university, was evaluated primarily upon the quality of the final essay. A grade for an essay was the main criterion of the applicant's level of knowledge. Such value of an essay was determined by the possibility to enter the university without examination provided that a final essay in the grammar school was highly rated. Thus, a final essay reflected both the resulting knowledge of pupils and the starting level of knowledge of applicants. It was the core of humanitarian education and effectively used both in the secondary and high school. Consideration of historical background of an essay allows us to formulate the principles of the methodological tradition, which may be used in the modern school.

Improving the model of the final literature essay is one of the acute problems discussed not only in the professional teaching environment, but also at the government level. The Russian President's proposals concerning the consideration of a literature essay as an exam on civil maturity and cultural identity, found an alive and grateful response from all those who care about the national education. But what will this essay be like, taking into account that over time it has already received the status of mandatory for all graduates? The opinions on this issue were rather dispersed: a philosophical essay, a problematic reasoning essay, an essay upon a given illustration of the literary work, a research project based on the literary material, the analysis of a movie episode, a spoken reply to the question, a detailed commentary on a literary quotation, etc. A number of various scenarios and proposals was increasing, but this did not clarify the situation. Nowadays, when the question of a genre of the final work was resolved, experts still have a lot to do in order to clarify the conception of an essay, its testing, the results of which should confirm the effectiveness of various solutions.
In pedagogical periodical press the materials about an essay are published under such colorful titles as "Pyrrhic victory of all Russian philologists", "An essay as a ray of light in the realm of darkness", "How to solve old issues in a new way". In the article "A final essay: the beginning of a long journey" a long way to the final essay is predicted, but the wording of the title "the beginning ... of the way ..." casts doubt on the entire existing tradition of the school essay in Russia, which is more than three hundred years [1]. The ten-year period from 2004 to 2014, when the essay has not been used, is not a reason to refuse the long-term experience of the essay at Russian school. As far back as 1811 in the Kharkov Imperial University it was considered as necessary to publish students' final school essays at the expense of the University, which also served as the entrance examination to the University [2]. As is well known, provided that a pupil successfully wrote a final school essay with at least "four points", till 70-ies of the $19^{\text {th }}$ century Russian universities entrants were automatically enrolled at the university [3]. It should be also noted that at those times an essay was not a "literary-critical essay": just like the "returned" essay, it was rather meta-objective.

The analysis of essays in higher forms of the grammar school in this period indicates the predominance of topics of a moral-ethical or historical nature, for example: "Summer and winter fun for girls" $\left(5^{\text {th }}\right.$ form); "Causes and consequences of the GrecoPersian Wars" ( $5^{\text {th }}$ form); "Causes of the development of education in south-western Russia in the $17^{\text {th }}$ century" $\left(6^{\text {th }}\right.$ form) [3]. In our opinion, the prevalence of such-like non-literary topics caused a certain methodical "provocation" - to write a general abstract reasoning essay. For example, such topic as "A very old man and a baby" ( $6^{\text {th }}$ form) [8]. A number of journalistic topics decreased only in the $7^{\text {th }}$ form and historical-literary topics with a comparative basis came to the fore, for

Corresponding author: sergej-zinin@yandex.ru

(C) The Authors, published by EDP Sciences. This is an open access article distributed under the terms of the Creative Commons Attribution License 4.0 (http://creativecommons.org/licenses/by/4.0/). 
example: "Tatiana and Olga in Pushkin's novel "Eugene Onegin" [3]. In general, we can affirm the dominance of humanitarian topics for essays in the higher forms. In the graduation class, along with literary topics, historical, geographical, autobiographical, historical-cultural topics were also popular, for example: "City and country", "Glass usefulness", "Life as a school", "Love your work, and it will love you", "Self-conquest is the greatest of victories", "Chekhovian intellectuals", "The cultural significance of the Renaissance" [3]. Even in the higher forms, essays were not limited to the history of literature. Firstly, in the essay they checked the ability to write well and only then the knowledge of historical and literary programs.

As for the present times, it should be noted that the traditional essay existed in the Russian school until 2004. Modern methods of teaching literature formulate the reasons for refusal of a final essay at school in different ways. Mandrikova G.M. in her article "An exam test in the form of an essay: differences and importance" assumes that the main reason for this is the collection of so-called "golden essays". According to the scientist, when such collections became available, "the process has lost its meaning and an essay has passed away" [4]. The editor of the magazine "Russian literature" Knyazhytsky A.I. noted the same: "Greedy publishers ruined a final essay in Russian schools" [5]. But a historical analysis shows that training aids with ready-made plans, theses and even texts of essays have appeared in Russia in large numbers in the late $19^{\text {th }}$ early $20^{\text {th }}$ century. Suffice it to recall the works of Samsonov V.A., Shumilovsky L.I. [6-7]. However, at that time the Ministry of National Education did not found it possible to cancel a final essay due to the presence of mass cribs. Consequently, all of these 500 or 300 "golden" essays were not the reason for the "death" of the essay. Similar cribs are more than a hundred years. Originally, children who were lagging behind their classmates used cribs. In our opinion, the trouble began when these cribs began to be used by students who performed well academically and qualified for a medal, which was the evidence of the loss of writing skills in the vast majority of students. Modern researchers in the search for the causes of failure of an essay previously used allow the interference of cause and effect: skills were lost not because pupils used cribs; cribs are just a consequence of the resulting systemic crisis of the essay. It happened largely due to the fact that the proposed topics became permanently frozen, too "encrypted" for the level of life experience of a teenager, they required template methods in covering topics that emasculated creativity from the process of essay writing. In other words, the shape ruined the content; that's when the essay passed away. By that time in the methodology the clichéd approaches to the genre of a final essay had spread; while mass consciousness had transformed these clichéd approaches into those "500 golden works".

Chertov V.F. analyzes the methodological errors of a final school essay in a broad historical context. The researcher assumes that the main obstacles in the historical development of the essay include nonconformity of topics and age abilities of pupils, as well as erroneous criteria for assessing written works. "A lot of mistakes have been already made when choosing topics for school essays and criteria for their assessment:

- at the beginning of the $20^{\text {th }}$ century, when the abilities of the pupils' age and their interests were not always taken into account;

- in the Soviet times, when many topics referred to obviously ready answers that one could find in a textbook;

- at the beginning of the $21^{\text {st }}$ century, when specifically literary themes and the ones that mostly did not affect the interests of the pupils" [8].

Along with topics of the revived essay, the genre of the essay is one of the main objects of the modern methodological research. At the same time, on the periphery of the methodical thought there are theses on possible unification of school subjects "Russian language" and "Literature", which could significantly transform both methodology of the essay and its genre specifics.

The possibility of unification of the Russian language and Literature refers us to the subject "Philology" that existed in the Russian school for the whole nineteenth century and at the beginning of the twentieth century. The main aim of the subject "Philology" was to study the language. In the grammar school plan in 1890 the aim of studying the Russian language and Literature, existing within a single subject, was as follows: "Teaching the Russian language and Literature in grammar schools should be aimed at learning how to express and write in your own language properly both in a grammatical and stylistic way" [9].

If we consider this historical experience in the context of the current situation, it should be recognized that in the unification of Russian language and Literature, a similar shift of goal-setting of the subject "Literature" and, in general, its reduction will take place. Dobrotina I.N writes about it. It is obvious for the methodologist that "the unification of these school subjects that certainly have points of intersection, and yet are distinct and independent, will not give the expected synergistic effect" [10].

Modern methodological articles are based on a number of approaches that ensure the success of the revived final essay. For instance, Mandrikova G.M. considers the systemic succession of the working methods of secondary and higher schools as an instrument for saving an essay. According to the scientist, universities refuse lectures, and the choice in favor of project-based education and independent work will force to move from a simple letter (writing down the lectures and making cribs) to writing activities (for example, a reflective creative essay) in any case.

Such activities can be successfully incorporated in school education, and, as a result of this education, brought to the final exam [4]. In our opinion, a direct connection of writing skills with methods of work in high school is a desired perspective; project education and reflective creative essays have not become the core of education of higher educational institutions.

Belyaeva N.V. in the magazine "Russian language at school" noted that when discussing and reflecting on the 
fate of the revived essay, almost nobody writes about the root causes of the need to return the essay to school. The methodist further discloses these causes: an essay should "motivate pupils to read belles-lettres and develop the skills to coherently express their own thoughts, as well as strengthen a humanitarian component of school education contributing to the formation of positive values in school leavers" [11]. In our opinion, an exam may not fully motivate an axiological process: this motivation is not sufficiently productive, it is not entirely obvious.

In the analysis published in the same issue of the magazine "Russian language at school", Dobrotina I.N. argues with some theses of the article written by Belyaeva N.V. First of all, she casts doubt on the idea that a well-read pupil can easily write an essay: "Not everyone can write a high-quality essay, and the fact of reading cannot help competently analyze the books, express one's views, be convincing in terms of logic and the skills of the text presentation" [10]. According to the methodist, writing an essay with the purpose to pass the Unified National Exam is worse than not to write at all, in such a way we shall continue to encourage the use of artificial (ritual) language instead of developing personality. What does Dobrotina I.N. call the artificial language? According to her logic, it is a fully developed language of school literature essays. The main feature of the ritual language is the repetition of formulas, and, as a consequence, the "erosion of language". Recognition of the artificiality of the language of school essays helps a methodist make the following conclusion: "It is rather difficult, maybe even impossible, to predict a real life situation, in which all the graduates will need the skills of a belles-lettres text analysis in the future" [10].

At the same time, the methodist is convinced that a final essay should be the work with literature: in his/her essay a pupil must demonstrate his/her knowledge of the belles-lettres text and know how to evaluate the understanding of why this fiction is classic.

The work of the Professor Bulokhov V.Y. discloses psycho-mental and psychological speech processes that are primary when a pupil creates his/her own texts. Bulokhov V.Y. unifies the abilities and skills of pupils to create their own texts in the semantic field "literary competence" [12]. Justifying the selected definition, the methodist notes that it should be translated into the Russian language, in contrast to such common definitions as "communicative" or, for example, "integrated linguistic-rhetorical". What methods does the scientist offer for formation of this competence? Firstly, the technique of delayed reading of the first variant of the essay; secondly, refusal of the ministerial standards in assessment of the essay. Bulokhov V.Y. specially focuses on a so-called "essay off the topic", which, according to ministerial regulations, are assessed with a negative mark. If we agree that the competence acquired in writing essays, is literary, then it is logical to consider the writer's experience, underlines the scientist. What makes writers frequently change the titles of their works? One of the main reasons is the fact that the lifelong material the author intends to describe, does not fit into preconceived plans, a "revolt" of characters and planned situations takes place [12]. Therefore, the article says, "it is difficult for both professional writers and students to work with the material to be described". Bulokhov V.Y. believes that "if the work does not correspond to the topic and the content allows to change the title, it is necessary to give a positive and even excellent first mark, if it corresponds to the degree of coverage of this "new" topic" [12]. Zinin S.A., one of the authors of this article, expresses his opinion in the same way: he disagrees with the proposals on the introduction of such a criterion in the literature essay within the Unified National Exam as the full coverage of the theme. Such a decision can cause strengthening of the subjective factor in the assessment of essays. In addition, according to Zinin S.A., "a demand of full coverage of the theme may lead in practice not to the assessment of the examinee's work, but to bringing its content in line with a prescribed pattern, compliance with which would have to be confirmed by an expert" [13]. Certainly, when assessing the literature essays we should be aware of the specifics of this school subject, consisting in the fact that a writer invites a reader to co-creation, free discussion of the text.

The current research proves that the information system of the Internet has a significant modeling impact on the pupil's essay. In the article of Belyaeva N.V., formulating the relevant problems in teaching to write essays at school, it has been noted that "it is difficult for pupils to perceive the printed text, as since early childhood they receive information from non-linear onscreen information sources" [14]. We agree with the position of Belyaeva N.V. and would like to add that the problem of written language learning by students is exacerbated, as at school there are philologists who did not written a final essay in its historically established form. In general, they read non-linear information and, therefore, have problems with written speech which they should teach pupils. Despite the commitment of the majority of modern methodologists to the historicalliterary topics of essays, it should be noted that the "revived" essay is deprived of its historical- literary topics and, in our opinion, this is not fatal. It is to be recalled that in the Russian school of the $19^{\text {th }}$ century topics of final essays were geographical, historical, cultural and historical-literary. One of the authors of this article, Getmanskaya E.V., wrote about it in her work: "History of essay in Russian education: the lost and the current": "The modern methods of school essays lost their broad humanitarian tendency of a Russian school of the late $19^{\text {th }}$ - early $20^{\text {th }}$ century. The hypertrophy of the literary-historical course, existing in high school today, is the result of a long, timely tracing of the university (academic) approaches to the study of literature in high school. In order to return a school essay in the category of exercises that contribute to the creative development of student skills and extensive humanitarian communication, it is worth to take a closer look at the experience of the Russian technique of the late $19^{\text {th }}$ early $20^{\text {th }}$ century, in which the development of written language was based not mainly on the historical and literary material, but on the ethical, cultural and general pedagogical subjects" [15]. Using historical models of 
the Russian school nowadays, an equally wide range of topics can be proposed.

An overview of current research, revealing the problems of the returned essay, shows that the main problematic issues include thematic transformation of essay, meta-methodical approaches to the text, the assessment criteria, the features of the formalized language of essay and, of course, the specifics of its genre. In our opinion, the analysis of essay genres will continue to dominate in the scientific and methodical analytics, as we are witnessing the birth of a new genre of a final essay - a publicistic essay with the use of literary materials.

\section{References}

1. R.Doschinsky, Teacher's Newspaper, 35, 42-43 (2014) [In Rus]

2. Essays of the students of the Don Cossack Host in the Imperial Kharkov University (Kharkov, 1811) [In Rus] 3. E.V. Getmanskaya, Successive connection of secondary and higher literary education in the Russian methodical tradition (Moscow, 2013) [In Rus] 4. G.M. Mandrikova, Public education, 6, 113-118 (2014) [In Rus]
5. A.I. Knyazhytsky, Russian philology, 2, 3-6 (2014) [In Rus]

6. V.A. Samsonov, Methodological guidance for conducting school essays (St. Petersburg, 1907) [In Rus]

7. L.I. Shumilovsky, Guidance for the independent compilation of student essays: Part I, Part II (St.

Petersburg, 1910) [In Rus]

8. V.F. Chertov, Scientific and methodological heritage of Russian philologists in the movement of eras

(Moscow, 2016) [In Rus]

9. An exemplary program of the school subject "Russian language with the Church Slavonic language" and philology, Magazine of the Ministry of the National Education, 12, 80-107 (1890) [In Rus]

10. I.N. Dobrotina, Russian Language at School, 5, 1417 (2014) [In Rus]

11. N.V. Belyaeva, Russian Language at School, 5, 8-13 (2014) [In Rus]

12. V.Y. Bulokhov, Russian Language at School, 5, 1822 (2014) [In Rus]

13. S.A. Zinin, Literature at School, 6, 22-24 (2014) [In Rus]

14. N.V. Belyaeva, Literature at School, 10, 20-22

(2014) [In Rus]

15. E.V. Getmanskaya, JLL, 5(4), 393-396 (2014). DOI:

$10.7813 / \mathrm{j} 11.2014 / 5-4 / 83$ 